\title{
TRABALHADORES RURAIS NO PARLAMENTO \\ O lobby da Contag na Câmara dos Deputados (2007-2015)
}

\author{
Barbara Salatiel Borges (1)
}

E-mail: barbarasalatiel.borges@gmail.com

\section{Paula Vivacqua de Souza Galvão Boarin (1) (D)}

E-mail: paulaboarin@hotmail.com

\section{Ciro Antônio da Silva Resende ${ }_{(1)}$ (i)}

E-mail: ciro.sr@hotmail.com

\section{Lucas Henrique Ribeiro da Silva}

E-mail: lucashenriquegeo@hotmail.com

(1) Universidade Federal de Minas Gerais (UFMG), Belo Horizonte - MG, Brasil.

DOI: $10.1590 / 3610502 / 2020$

\section{Introdução}

Embora a questão rural tenha sido um tema importante para as ciências sociais, especialmente devido à centralidade da União Democrática Ruralista (UDR) na defesa dos proprietários rurais durante o processo constituinte, a literatura nacional sobre grupos de interesse, a exemplo de Mancuso (2007) e Santos (2011), tem se concentrado na agenda legislativa da indústria, notadamente a da Confederação Nacional da Indústria (CNI). Com a finalidade de preencher tal lacuna, este artigo busca compreender sob quais condiçóes se dá o sucesso legislativo dos trabalhadores rurais na Câmara dos Deputados no Brasil, partindo, para tanto, da análise de proposiçôes de interesse da Confederação Nacional dos Trabalhadores e Trabalhadoras na Agricultura (Contag).

Artigo recebido em: 02/05/2019

Aprovado em: 12/02/2020
Resultado da luta histórica do campo por representação política, a Contag foi formada em 1963 e reconhecida pelo governo em 1964. Representando os trabalhadores rurais e pequenos produtores, a entidade mantém uma agenda centrada em temas como relaçóes de trabalho, seguridade social, reforma agrária, acesso ao crédito e qualidade de vida no campo, sendo atualmente formada por mais de $4 \mathrm{mil}$ sindicatos rurais e 27 federações estaduais (Contag, 2003b; 2018). A análise de sua atuação política, sob a perspectiva dos grupos de interesse, parte das transformaçóes provocadas pela promulgação da Constituição Federal de 1988 no sistema de representação, que passou a combinar sua herança corporativista a práticas pluralistas de influência. Assim, a arena congressual, sobretudo a Câmara dos Deputados, passou a atrair diversos grupos que buscam impactar o comportamento parlamentar conforme seus objetivos políticos (Diniz \& Boschi, 2004; Mancuso, 2007). Analisar quais práticas são 
mobilizadas por esses grupos de interesse, e sob quais condiçôes estes são bem-sucedidos, é essencial para a compreensão da dinâmica e dos resultados produzidos no parlamento.

Desse modo, diante de um número de casos relativamente limitado ( $\mathrm{N}$ intermediário), a estratégia empírica aqui empreendida consiste no uso de Qualitative Comparative Analysis (QCA), método que permite proceder à análise sistemática de combinaçóes de condiçôes causais, com vistas a identificar configuraçôes que produzem determinado resultado de interesse. Naquilo que se refere às variáveis consideradas na análise, tem-se o sucesso legislativo da Contag como a variável dependente, comportando-se de forma dicotômica (sucesso e insucesso). Já as condições causais são: 1. alinhamento ao Poder Executivo; 2. mobilização de massa; 3. presença de grupos opositores; e 4 . opiniāo pública. $\mathrm{O}$ artigo começa por uma descrição da trajetória política da Contag e de sua atuação na arena legislativa; em seguida, apresenta os casos selecionados, o cálculo da taxa de sucesso e os resultados da aplicação do QCA, à luz das principais contribuiçóes do campo de estudos sobre os grupos de interesse.

\section{A trajetória da atuação política da Contag}

No Brasil, a institucionalização da questão rural esteve, desde o início do processo de modernizaçáo, na passagem para o século XX, concentrada no patronato rural. Já em 1903, com o Decreto 979, regulamentou-se as organizaçóes de proprietários de terra e os sindicatos patronais. Nos anos 1940 , ainda que $60 \%$ dos brasileiros vivessem no campo, a Consolidação das Leis Trabalhistas (CLT, 1943) restringia-se aos trabalhadores urbanos. Somente duas décadas depois, com as discussões sobre a estrutura agrária do país, foi criado, em 1963, o Estatuto do Trabalhador Rural, que concedia direito à aposentadoria aos trabalhadores do campo (Contag, 2003a).

Diante de tantos entraves ao reconhecimento e aprofundamento dos direitos dos trabalhadores rurais, movimentos como as Ligas Camponesas, o Movimento dos Agricultores Sem Terra (Master), a Ação Popular (AP) e a União dos Lavradores e Trabalhadores Agrícolas do Brasil (Ultab), entre outros, contribuíram para a aceleração do reconhecimento das organizações de trabalhadores rurais em sindicatos. Assim, em 1963, foi realizada a $1^{\text {a }}$ Convenção Brasileira de Sindicatos Rurais, convocada pela Ultab. À época, dos 475 sindicatos existentes no país, somente 220 eram reconhecidos. Entre as demandas consolidadas na Convenção estavam a reforma agrária e a criação de uma confederação nacional de trabalhadores da agricultura (Contag, 2003a).

Como reação, um setor conservador dos trabalhadores rurais, ligado à Igreja Católica, fundou a Confederação Nacional dos Trabalhadores na Agricultura (CNTA). Pressionado pela disputa que se seguiu, o Ministério do Trabalho determinou que fosse realizado um congresso nacional de trabalhadores rurais, a fim de que fosse criada, em definitivo, uma entidade representativa que deveria abarcar as 27 federaçóes reconhecidas oficialmente à época, de um total de 42 . Assim, em 22 de dezembro de 1963, trabalhadores rurais de dezoito estados decidiram pela criaçáo da Confederação Nacional dos Trabalhadores na Agricultura (Contag), que seria reconhecida, em 31 de janeiro de 1964, pelo Decreto Presidencial 53.517.

Devido ao período em que foi criada, a Contag sofreu intervençóes dos governos do regime militar já no início de sua trajetória, como a substituição de sua presidência e a prisão dos líderes sindicais mais comprometidos com a reforma agrária. De modo geral, o regime militar "colocou à margem a pequena produção e favoreceu a ampliação da concentração de terra e de renda no país" (Contag, 2003a, p. 21). Ainda assim, em grande medida, as demandas da Confederação resistiram às imposiçôes, e o Estatuto da Terra, elaborado durante o governo João Goulart, foi promulgado pelo general Humberto Castelo Branco.

Nos anos 1980, a Contag integrou o conjunto de organizaçôes, movimentos sociais e setores da sociedade que reivindicaram o fim do regime militar, a convocação da Assembleia Nacional Constituinte e as eleiçóes diretas. Ao longo do processo constituinte, não houve avanços quanto à reforma agrária, sobretudo no que toca à sua desassociação da desapropriação por interesse social, uma das principais reivindicaçóes da Contag e dos demais movimentos voltados para os trabalhadores rurais, especialmente em função da atuação da UDR. Ainda assim, a entidade participou 
dos debates travados ao longo do processo constituinte, "alcançando significativas conquistas, como a inclusão dos rurais no Regime Geral da Previdência Social e a extensão dos direitos trabalhistas aos assalariados(as) rurais" (Contag, 2018, s/n).

A reforma agrária, contudo, manteve-se no centro das reivindicaçôes da Contag nos anos 1990, período no qual os conflitos no campo se acirraram. Em 1995, 2 mil trabalhadores rurais participaram, em Brasília, do $6^{\circ}$ Congresso Nacional dos Trabalhadores Rurais (CNTR). Além de condenar a política neoliberal de Fernando Henrique Cardoso, que iniciava seu primeiro mandato naquele ano pelo Partido da Social Democracia Brasileira (PSDB), o encontro definiu a filiação da Confederação à Central Única dos Trabalhadores (CUT) (Contag, 2003a). Já em 1998, durante o $7^{\circ}$ Congresso Nacional de Trabalhadores e Trabalhadoras Rurais (CNTTR), foi aprovado o Projeto Alternativo de Desenvolvimento Rural Sustentável e Solidário (PADRSS), uma estratégia de enfrentamento das políticas neoliberais que seria aprofundada nos anos seguintes e se tornaria parte das reivindicaçôes dos trabalhadores rurais.

A Contag considerou um marco a criaçáa, em 2000, do Ministério do Desenvolvimento Agrário (MDA), uma reinvindicação histórica do Movimento Sindical de Trabalhadores e Trabalhadoras Rurais (MSTTR). Em 2003, quando Luiz Inácio Lula da Silva assume a presidência da República pelo Partido dos Trabalhadores (PT), a Marcha das Margaridas reúne 40 mil mulheres em Brasília (Contag, 2003b). Já em 2009, realiza-se o $10^{\circ}$ CNTTR, que reafirma a centralidade do PADRSS (Contag, 2009).

De lá para cá, a Contag acumulou conquistas significativas, entre as quais se destacam o Programa Nacional de Fortalecimento da Agricultura Familiar (Pronaf), o Programa de Aquisição de Alimentos (PAA), o Programa Nacional de Alimentação Escolar (Pnae), o Programa Nacional de Educação do Campo (Pronacampo), o Programa Nacional de Habitaçáo Rural (PNHR) e a Política Nacional do Trabalhador Rural Empregado (Pnatre) (Contag, 2013a). Cabe ressaltar que, de acordo com Scherer-Warren (2007), a entidade compóe uma organização política em rede, baseada em elos estratégicos e no princípio da horizontalidade; assim, suas pautas e, portanto, suas conquistas não estão descoladas da ação política de outros movimentos, como o Movimento dos Trabalhadores Rurais Sem Terra (MST) e a Federação dos Trabalhadores da Agricultura Familiar (FETRAF). Desse modo, já no $3^{\circ}$ CNTR, em 1979, a Contag optou por "atuar em Açóes Coletivas, que hoje chamamos de açóes de massa" (Contag, 2003a, p. 28).

Assim, além do PADRSS, o MSTTR e, consequentemente, a Contag tem entre as suas principais bandeiras de luta: 1. reforma agrária; 2. agricultura familiar; 3. direitos dos assalariados rurais; 4. políticas sociais para o campo; 5. relaçôes de gênero e de geração; 6 . agroecologia; e 7. reforma política. Ao longo de sua trajetória, a Contag compôs, ainda, o cenário das negociaçôes internacionais a respeito da liberalização agrícola, especialmente aquelas que transcorreram no âmbito da Organizaçáo Mundial de Comércio (OMC) (Carvalho, 2010) e do Mercosul (Carvalho, 2011).

Para comunicar à base e à sociedade em geral sobre sua atuaçáo, a entidade conta com o Jornal da Contag, com ediçóes online, e com o programa de rádio $A$ voz da Contag, "considerada a mais duradoura experiência de rádio no movimento sindical brasileiro, e uma das mais importantes neste meio" (Contag, 2018, s/n). Em sua organização, a Confederação tem como instâncias deliberativas o Congresso Nacional dos Trabalhadores Rurais, que realizou sua décima primeira edição em 2013, e o Conselho Deliberativo, composto por diretores da Contag e das federaçôes filiadas. Quanto às instâncias consultivas, a entidade prevê em seu estatuto a convocação de reuniōes plenárias das quais participam as federaçóes e os sindicatos filiados. Há, ainda, nove Coletivos Nacionais, que se organizam em torno de temáticas-chave para a Contag, e três Comissóes Nacionais: 1. de mulheres trabalhadoras rurais; 2 . da juventude; $\mathrm{e} 3$. da terceira idade. Já a instância de fiscalizaçẫo é composta pelo Conselho Fiscal e pela Comissão Nacional de Ética (Contag, 2018).

Com o objetivo de efetuar a articulação entre a Confederação e as federaçôes de sua base, a entidade dispōe de cinco regionais (Centro-Oeste, Norte, Nordeste, Sudeste e Sul). Suas atividades compreendem: 1. divulgação e acompanhamento das políticas e açôes da Contag nas federaçôes filiadas; 2 . debate e formulação 
de propostas voltadas para questóes regionais dentro das políticas de âmbito nacional; 3. recolhimento de demandas e sugestóes; e 4. articulação e suporte às açóes conjuntas das federaçóes na esfera regional. Cada regional é composta por uma coordenação, que compreende de três a cinco membros, respeitando, obrigatoriamente, a participação de um mínimo de $30 \%$ de mulheres e de $20 \%$ de jovens, além de representante(s) da terceira idade (Contag, 2018).

Como foi definido ainda durante o regime militar, as ações de massa da Contag se constituem na principal estratégia política do MSTTR. Partindo da proposta e negociação de políticas públicas, as mobilizações têm caráter reivindicativo e de negociação, voltando-se para as pautas do PADRSS. Nesse sentido, destacam-se o Grito da Terra Brasil, a Marcha das Margaridas, a Mobilização Nacional dos Assalariados e Assalariadas Rurais, o Festival Nacional da Juventude Rural e a Jornada de Luta pela Reforma Agrária (Contag, 2018).

\section{A Contag na arena legislativa redemocratizada}

Com a promulgação da Constituição Federal de 1988, o Poder Legislativo passou a ter novo papel na formulação de políticas públicas, o que impactou o sistema de representação de interesses brasileiro. Assim, ainda na década de 1980, deu-se a desconstrução do modelo desenvolvimentista iniciado com Getúlio Vargas e a eliminação dos espaços de negociação corporativa no aparelho executivo estatal. No plano do desenho institucional e da reforma do Estado, a transição foi dual, com reformas orientadas para o mercado, já nos anos 1990, e o aprofundamento das instituições democráticas (Diniz \& Boschi, 2004).

O sistema de representação de interesses passou a se interconectar com o sistema de representação política, observando-se a emergência de um híbrido: antigos interesses organizados sob o modelo corporativo, e novos grupos de interesse assumindo formatos mais pluralistas se combinam em uma estrutura fragmentada que busca formas de se articular com o Estado (Diniz \& Boschi, 2004). As organizaçôes que integram o sistema corporativo e as associaçóes livres passaram a disputar acesso ao processo decisório, vocalizando suas preferências e buscando influenciar os resultados políticos. Para tanto, empregam-se diferentes estratégias a partir da mobilização de recursos variados; a arena congressual, em especial a Câmara dos Deputados, se destaca como lócus central para a competição por influência (Diniz \& Boschi, 2004; Mancuso, 2007; Santos, 2011).

No que toca à arena parlamentar, os estudos sobre grupos de interesse investigam o impacto de suas atividades no comportamento dos congressistas a partir, sobretudo, das doaçóes de campanha e das atividades de lobby (Baumgartner \& Leech, 1998; Scarrow, 2007; Stratmann, 2005). Conforme Santos et al. (2015), se alguns autores não identificam influência do financiamento de campanhas eleitorais sobre a atividade parlamentar (Dow \& Endersby, 1994; Bronars \& Lott, 1997; Wawro, 2001), outros consideram este efeito significativo (Hall \& Wayman, 1990; Davis, 1993; Stratmann, 2002; Holian; Krebs \& Walsh, 1997). Alguns estudos argumentam que esta relação se dá somente sob determinadas condiçóes (Wright, 1990; Abler, 1991; Langbein, 1993), entre elas o uso de práticas de lobby por parte dos grupos de interesse, como apontado por Sabato (1985) e Evans (1986).

Diferentemente do que acontece nos Estados Unidos, país que conta com volume significativo de pesquisas sobre o tema (Baumgartner \& Leech, 1998), a literatura nacional a respeito é escassa. Entre os poucos estudos, figuram Santos et al. (2015), que analisam votaçôes nominais em matérias legislativas na Câmara dos Deputados (1999-2007), face ao resultado de interesse da CNI. Os autores indicam que o financiamento corporativo exerce influência positiva sobre a cooperação legislativa. Igual cenário de escassez se constata nas análises voltadas à pluralidade de grupos de interesse envolvidos rotineiramente em práticas de lobby no Congresso Nacional; algumas das principais contribuições para o campo, como Mancuso (2007) e Santos (2011), se concentram no empresariado. ${ }^{1}$ É necessário, portanto, que novas pesquisas abarquem grupos cujas estratégias de influência e grau de sucesso legislativo sejam pouco conhecidos, como os trabalhadores e trabalhadoras rurais representados pela Contag.

Considerando que o lobby e a representação sistemática de interesses têm custos elevados e exigem a mobilização de recursos por parte dos grupos de pressão, a mobilização cada vez maior desses grupos visando atuar no parlamento parece um indicador relevante 
para confirmar, como já dito, as duas proposiçóes que a literatura vem sugerindo. A primeira é que o Legislativo foi revalorizado como espaço decisório, convertendo-se em uma arena política relevante no período pós-1988. A segunda é que o pluralismo vem aumentando, acompanhado por uma observação cada vez mais criteriosa do Estado (Santos, 2014, p. 18).

Em seu sítio eletrônico, a Contag oferece acesso a um banco de dados que armazena as proposições legislativas de seu interesse que tramitam na Câmara dos Deputados e no Senado Federal. Na primeira Casa, constam cerca de 820 proposiçốes legislativas no período entre 1989 e 2018. Em termos absolutos, de 1989 a 1994 constam apenas seis proposiçóes, enquanto que entre 1995 e 2002, isto é, no governo de Fernando Henrique Cardoso, elas são 37. Já ao longo do governo Lula, entre 2003 e 2010, registra-se o expressivo número de 195 proposiçóes de interesse da entidade. Ainda mais expressivo é o número registrado no primeiro mandato de Dilma Rousseff: 250. Nos anos seguintes, marcados pelo impeachment da presidente eleita e a ascensão de Michel Temer ao poder, constam 355 proposiçóes. A partir do gráfico 1, abaixo, é possível visualizar esse interesse da Contag no tempo.

A gradaçáo dos valores observados pode estar associada à profissionalização progressiva da entidade em termos de representação de interesses. Vale observar o ano de 2015, que se destaca, com 190 proposiçóes legislativas de interesse na Casa. O banco de dados registra o posicionamento da entidade diante de somente 52 das proposiçôes legislativas consideradas de seu interesse na Câmara dos Deputados. Das 52, a Contag se afirma favorável a 22, contrária a 24 e indiferente a seis.

O banco disponibilizado pela Contag permite, ainda, realizar buscas por temáticas, sendo elas: 1. agrária; 2. agrícola; 3 . sociais; 4 . juventude; 5 . Lei de Diretrizes Orçamentárias - LDO; 6. meio ambiente; 7. mulheres; 8 . organização sindical; 9. reforma política; 10. reforma tributária; 11. relações de trabalho; 12. relaçóes internacionais; e 13. terceira idade. As áreas que apresentam maior percentual de proposiçóes de interesse sáo a agrícola (26\%) e meio ambiente $(15 \%)$. Relaçóes de trabalho e a pauta agrária correspondem a $13 \%$, cada uma, enquanto pautas sobre mulheres registram $12 \%$, e as sociais, $11 \%$. Relaçôes internacionais, juventude rural, terceira idade e reforma política respondem, juntas, por apenas $6 \%$ do total; organização sindical, a $4 \%$. Os percentuais relativos a $\mathrm{LDO}$ e reforma tributária são inexpressivos.

\section{Casos selecionados e taxa de sucesso na Câmara dos Deputados}

Os dados utilizados aqui se referem à agenda legislativa da Contag entre 2007 e 2015, e foram disponibilizados pela instituiçáo. Deles, selecionamos as

\section{Gráfico 1}

Interesse da Contag em proposiçóes legislativas da Câmara dos Deputados (1989-2017)

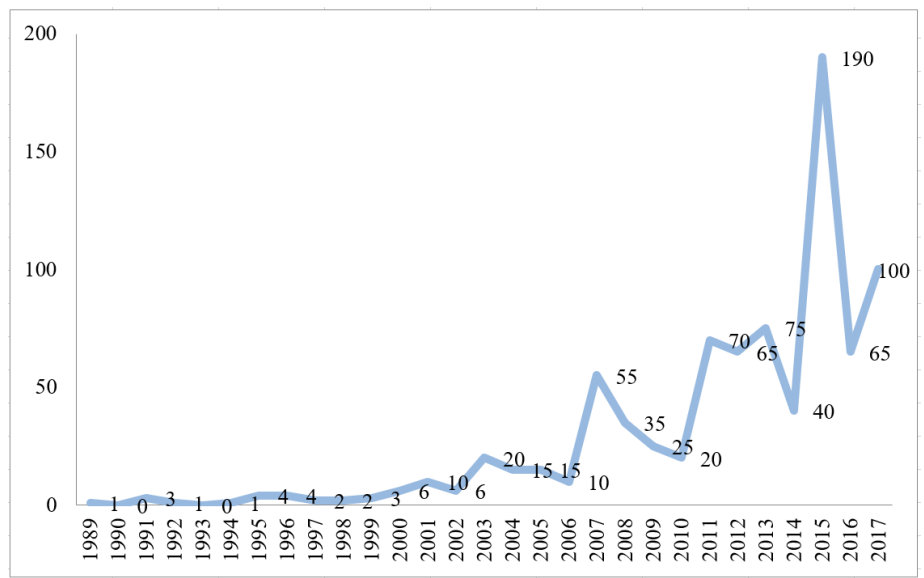

Fonte: Elaborado pelos autores a partir de dados da Contag (2018). 
27 proposições legislativas que já tiveram seu processo legislativo encerrado. Estas constam em documentos de reivindicaçóes divulgados pela entidade, como o Grito da Terra Brasil. Ao restringir a seleção às proposições cuja tramitação se encerrou, buscamos considerar os resultados políticos produzidos na arena legislativa, diante dos interesses da Contag.

No período em estudo, parte significativa das proposiçóes de interesse foram projetos de lei (PL): quinze, ou $60 \%$ do total. Os projetos de lei complementar (PLP) foram quatro (16\%), enquanto os projetos de lei de conversão $(\mathrm{PLV})^{2}$ e as propostas de emenda à Constituição (PEC) somaram seis (12\% cada). Do total, somente cinco proposiçôes são de autoria do Poder Executivo, tendo quatro sido apresentadas durante os governos do PT e uma no governo do PSDB. Doze das 27 proposiçóes são de autoria de deputados federais ligados ao PT, o que demonstra forte envolvimento do partido com questóes de interesse da Contag. A tabela 1, abaixo, lista todas as proposiçóes.

O PLV 08/2008, originado da medida provisória (MP) 410/2007, versava sobre a aposentadoria do trabalhador rural. Para a Contag, favorável à proposição, o PLV representava a redução da informalidade do trabalho no meio rural, especialmente no que se refere às modalidades temporárias. De acordo com o deputado federal Assis do Couto (PT-PR), relator da matéria, a medida expressou "o resultado de exaustivas negociaçóes estabelecidas entre representantes dos trabalhadores rurais e o Governo Federal - cito aqui a presença da CONTAG” (Brasil, 2008a, p. 111). O projeto deu origem à Lei 11.718/2008. Já o PLV 08/2009 se originou da MP 455/2009, conhecida como a "MP da merenda escolar". A proposição destinava um mínimo de 30\% dos recursos financeiros repassados pelo Fundo Nacional de Educação (FNDE) para a compra de alimentos vindos "diretamente da agricultura familiar e do empreendedor familiar rural ou de suas organizaçôes" (Brasil, 2009). Aprovado com apoio da Contag, o PLV deu origem à Lei 11.947/2009. De acordo com Alessandra Lunas, então vice-presidente da entidade, a mobilização dos trabalhadores rurais foi fundamental para a aprovação.

O PLV 09/2009, por sua vez, teve origem na "MP da Amazônia" (458/2009), que permitia à
União transferir terrenos seus de até 1,5 mil hectares na Amazônia Legal, sem licitação, para aqueles que detinham sua posse antes de dezembro de 2004. Convertida no PLV 09/2009, a proposição foi alterada para possibilitar que áreas ocupadas por terceiros fossem regularizadas e que pessoas jurídicas participassem das licitações para a sua regularização. ${ }^{3}$ Em 25 de junho de 2009, a proposiçáo foi sancionada pelo entâo presidente Lula com dois vetos, de modo que as terras ocupadas por empresas ou representantes indiretos não pudessem ser regularizadas - o que atendia ao interesse da Contag, de ambientalistas e de procuradores da República. A Contag foi contrária à aprovação da proposição - o argumento era que esta favoreceria a "grilagem" de terras e o desmatamento florestal, acentuando os conflitos no campo.

A PEC 138/2003, conhecida como "PEC da juventude", foi apresentada pelo deputado federal Sandes Junior (PP-GO). Em novembro de 2008, a votação em segundo turno aprovou a proposição com 382 votos favoráveis, nenhum contrário e uma abstenção, dando origem à emenda constitucional 65/2010.

O PL 203/1991, de autoria do senador Francisco Rollemberg (PFL-SE), versava sobre a Política Nacional de Resíduos Sólidos. Sua aprovação teve o apoio da Contag. O processo legislativo em torno do PL, que durou mais de vinte anos e envolveu inúmeras outras proposiçóes, envolvia ampla rede de interesses. Foram criadas comissóes especiais que não exauriram os conflitos em torno da matéria; em 2008, constituiu-se um grupo de trabalho na Câmara dos Deputados coordenado pelo deputado federal Arnaldo Jardim (PPS-SP). A aprovação em plenário ocorreu em 2010, sob a relatoria do deputado federal Dr. Nechar (PP-SP). Após a sanção presidencial, o projeto foi convertido na Lei $12.305 / 2010$.

A Contag também apoiou o PL 231/2007, de autoria do deputado federal Domingos Dutra (PT-MA), que dispunha "sobre a proibição da derrubada de palmeiras de babaçu nos estados do Maranhão, Piauí, Tocantins, Pará, Goiás e Mato Grosso" (Brasil, 2007). A despeito de uma ampla mobilização, em especial das trabalhadoras rurais, o projeto foi arquivado duas vezes. Já o PLP 306/2008, de autoria do senador Tião Viana (PT-AC), dispunha "sobre os valores mínimos 
Tabela 1

Agenda legislativa da Contag - Casos selecionados

\begin{tabular}{|c|c|c|c|c|}
\hline Proposição & $\begin{array}{c}\text { Ano } \\
\text { Conclusáo }\end{array}$ & Autoria & $\begin{array}{l}\text { Partido do } \\
\text { Autor }\end{array}$ & $\begin{array}{l}\text { Posicionamento } \\
\text { Contag }\end{array}$ \\
\hline PLV 08/2008 & 2008 & Assis do Couto & PT & Favorável \\
\hline PLV 08/2009 & 2009 & Carlos Abicalil & PT & Favorável \\
\hline PLV 09/2009 & 2009 & Asdrubal Bentes & PMDB & Contrário \\
\hline PEC 138/2003 & 2010 & Sandes Júnior & $\mathrm{PP}$ & Favorável \\
\hline PL 203/1991 & 2010 & Senado Federal (Francisco Rollemberg) & $(\mathrm{PFL})$ & Favorável \\
\hline PL 231/2007 & 2015 & Domingos Dutra & PT & Favorável \\
\hline PLP 306/2008 & 2012 & Senado Federal (Tião Viana) & PT & Favorável \\
\hline PLP 362/2006 & 2014 & Poder Executivo & - & Favorável \\
\hline PLP 363/2006 & 2011 & $\begin{array}{l}\text { João Alfredo, Adão Pretto, Anselmo, Jamil } \\
\text { Murad, Luci Choinacki, Zé Geraldo }\end{array}$ & $\begin{array}{l}\mathrm{PSOL} / \mathrm{PT} / \mathrm{PT} / \\
\mathrm{PCdoB} / \mathrm{PT} / \mathrm{PT}\end{array}$ & Favorável \\
\hline PEC 394/2005 & 2011 & Reginaldo Lopes & PT & Favorável \\
\hline PL 490/1995 & 2015 & Domingos Dutra & PT & Favorável \\
\hline PLP 591/2010 & 2011 & $\begin{array}{l}\text { Vignatti, Antonio Carlos Chamariz, Carlos } \\
\text { Melles, outros }\end{array}$ & $\mathrm{PT} / \mathrm{PTB} / \mathrm{DEM}$ & $\begin{array}{l}\text { Favorável com } \\
\text { ressalvas }\end{array}$ \\
\hline PL 939/2011 & 2015 & Luci Choinacki & PT & Favorável \\
\hline PL $1.463 / 2011$ & 2017 & Sílvio Costa & PTB & Contrário \\
\hline PDC $2.841 / 2010$ & 2012 & $\begin{array}{l}\text { Representação brasileira no Parlamento do } \\
\text { Mercosul }\end{array}$ & - & Favorável \\
\hline PL 3.979/2008 & 2016 & Adão Pretto & $\mathrm{PT}$ & Favorável \\
\hline PL 4.302/1998 & 2017 & Poder Executivo & - & Contrário \\
\hline PL $4.529 / 2004$ & 2013 & $\begin{array}{l}\text { Comissáo Especial destinada a acompanhar e } \\
\text { estudar propostas de políticas públicas para a } \\
\text { juventude. }\end{array}$ & - & Favorável \\
\hline PL 5.887/2009 & 2015 & Valdir Colatto & PMDB & Contrário \\
\hline PL 5.898/2009 & 2011 & Assis do Couto e Anselmo de Jesus & $\mathrm{PT} / \mathrm{PT}$ & Favorável \\
\hline PL 5.914/2009 & 2011 & Poder Executivo & - & Favorável \\
\hline PL 6.852/2006 & 2010 & Poder Executivo & - & Favorável \\
\hline PL 7.113/2006 & 2007 & $\begin{array}{l}\text { Joáo Alfredo, Adão Pretto, Anselmo, Jamil } \\
\text { Murad, Luci Choinacki, Zé Geraldo }\end{array}$ & $\begin{array}{l}\mathrm{PSOL} / \mathrm{PT} / \mathrm{PT} / \\
\mathrm{PCdoB} / \mathrm{PT} / \mathrm{PT}\end{array}$ & Favorável \\
\hline PL 7.332/2010 & 2017 & Senado Federal (Tarso Jereissati) & PSDB & Contrário \\
\hline PL 8.035/2010 & 2014 & Poder Executivo & - & Favorável \\
\hline PEC 438-A/2001 & 2014 & Senado Federal (Ademir Andrade) & PSB & Favorável \\
\hline PL $8.023-A / 2010$ & 2012 & CAPADR & & Favorável \\
\hline
\end{tabular}

Fonte: Elaborado pelos autores a partir de dados da Contag (2018).

a serem aplicados anualmente por Estados, Distrito Federal, Municípios e União em ações e serviços públicos de saúde" (Brasil, 2008b). Sua tramitação ocorreu em regime de urgência; foi analisado pelas comissóes de Seguridade Social e Família (CSSF), Finanças e Tributação (CFT), Constituição e Justiça e de Cidadania (CCJC), além do plenário. Ao lado de diversas outras entidades, a Contag mobilizou-se pela aprovação. Assim, sua transformação em norma jurídica (Lei Complementar 141/2012) foi considerada uma vitória para os movimentos sociais.

O PLP 362/2006, de autoria do Poder Executivo, ficou conhecido como "PLP da sucessão rural" por autorizar "a concessão de financiamento, por meio do Banco da Terra, ao beneficiário de imóvel rural objeto de partilha decorrente de direito de herança” (Brasil, 2006). A justificativa do Poder Executivo era evitar a desagregação da cultura e das tradiçốes da 
agricultura familiar, centradas na família como unidade de produção. Contando com o apoio da Contag, a proposição foi convertida na Lei Complementar $145 / 2014$.

Por seu turno, o PLP 363/2006 foi proposto pelos deputados federais Joáo Alfredo (PSOL-CE), Adão Pretto (PT-RS), Anselmo (PT-RO), Jackson Barreto (PTB-SE), Jamil Murad (PCdoB-SP), Luci Choinacki (PT-SC) e Zé Gerardo (PMDB-CE). Seu objetivo era estabelecer critérios para a tramitação de açôes de desapropriação de imóveis rurais. Fruto das recomendaçôes incluídas no parecer da Comissão Parlamentar Mista de Inquérito da Terra, a expectativa era a facilitação da reforma agrária. O PLP, que por sua natureza deve tramitar em regime de prioridade, não recebeu parecer da $\mathrm{CCJC}$ e foi arquivado nos termos do artigo 105 do Regimento Interno da Câmara dos Deputados. Seu desarquivamento ocorreu na legislatura seguinte, embora o parecer na CCJC, de relatoria do deputado federal Nelson Trad (PMDB-MS), tenha sido pela rejeição. Assim, em 2011, o PLP foi novamente arquivado.

O PL 5.887/2009, de autoria do deputado federal Valdir Colatto (PMDB-SC), submetia ao Congresso Nacional as desapropriaçōes de imóveis rurais por interesse social, para fins de reforma agrária. Para a Contag, contudo, a medida inviabilizaria a reforma agrária no país, ao garantir a latifundiários a possibilidade de explorar a terra sem compromisso com o preceito constitucional que prevê seu uso social. Em 2015, a proposição foi arquivada. Já o PL 5.898/2009, apresentado pelos deputados federais Assis do Couto (PT-PR) e Anselmo de Jesus (PT-RO), teve sua aprovaçáo apoiada pela Contag. A medida acrescentava e alterava dispositivos da Lei 4.771, de 1965, e da Lei 11.428, de 2006, definindo pequena propriedade rural e posse rural familiar, $\mathrm{e}$ garantindo a realização de atividades produtivas em áreas de preservação permanente. O PL 5.898/2009 foi apensado ao PL 1.876/1999 e transformado na Lei 12.651/2012, conhecida como Novo Código Florestal.

Já o PL 5.914/2009, de autoria do Poder Executivo, tratava da criação de cargos em comissão e funçôes de confiança destinados ao Instituto Nacional do Seguro Social (INSS), tendo sua aprovaçấo apoiada pela entidade. O projeto foi convertido na Lei 12.406/2011. Também apresentado pelo Executivo e associado à seguridade social, o PL 6.852/2006 facilitava o acesso à aposentadoria por trabalhadores rurais sem condiçōes de comprovar vínculo empregatício. A proposiçāo foi apensada ao PL 1.154/1995, entáo arquivado.

A Contag foi favorável à aprovação do PL 7.113/2006, de autoria dos deputados federais João Alfredo (PSOL-CE), Adão Pretto (PT-RS) e Anselmo (PT-RO), entre outros, que alterava e acrescia dispositivos à Lei 8.629/1993, visando estabelecer critérios para a desapropriação de terras rurais para reforma agrária, e revogando o artigo 20-A da MP 2.183-56, de 2001. Em 2007, a proposiçáo foi arquivada. O PL 7.332/2010, apresentado pelo senador Tasso Jereissati (PSDB-CE), versava sobre a criação do Programa Bolsa Família, conferindo benefício adicional vinculado ao desempenho escolar. Embora favorável ao Programa, a entidade se posicionou contra a vinculação, alegando os efeitos deletérios de delegar "à criança e ao/ a adolescente, os membros mais frágeis no núcleo familiar, a responsabilidade individual pelo sucesso escolar, desconsiderando o processo como um todo, especialmente, a política educacional e a social" (Contag, 2013b, p. 15).

Por seu turno, o PL 8.035/2010, que tratava do Plano Nacional de Educação para o decênio 2011-2020, foi apresentado pelo Poder Executivo e contou com o apoio dos trabalhadores rurais por reconhecer as especificidades das populaçóes do campo. A proposição foi transformada na Lei 13.005/2014. A PEC 438-A/2001, apresentada pelo senador Ademir Andrade (PSB-PA), dava nova redaçáo ao artigo 243 da Constituição Federal, estabelecendo a expropriaçăo de áreas onde fosse constatada a exploração de trabalho escravo. Também contou com o apoio da Contag, assim como o PL 8.023-A/2010, de autoria da Comissáo de Agricultura, Pecuária, Abastecimento e Desenvolvimento Rural (CAPADR), que dispunha sobre a integração vertical na agropecuária. A PEC 438-A/2001 foi transformada na Emenda Constitucional 81/2014, ao passo que o PL 8.023-A/2010 foi apensado ao PL 4.378/1998, que se encontra arquivado.

A PEC 394/2005, de autoria do deputado federal Reginaldo Lopes (PT-MG), incluía o termo "jovem" no artigo 227 da Constituição Federal de 1988, 
e incentivava a criação de unidades de referência juvenil. A Contag manifestou apoio à matéria, que, entretanto, foi arquivada. Já o PL 490/1995, proposto pelo deputado federal Domingos Dutra (PT-MA), proibia a concessão de medidas liminares, com ou sem audiência de justificação prévia, em litígios coletivos pela posse da terra urbana ou rural. A Contag, favorável à aprovação, defendeu que a medida "procura fazer com que juízes e promotores conheçam os fatos antes do deferimento de liminares de despejo, evitando assim que injustiças e violências sejam cometidas, a exemplo dos massacres de Eldorado dos Carajás e Corumbiara" (Contag, 2013b, p. 5).

Quanto ao PLP 591/2010, de autoria dos deputados federais Vignatti (PT-SC), Antonio Carlos Chamariz (PTB-AL), Carlos Melles (DEM-MG) e outros, houve ressalvas. A medida propunha mudanças na legislação que regula o Estatuto Nacional da Microempresa, da Empresa de Pequeno Porte e do Microempreendedor Individual. Para a entidade, algumas das mudanças propostas representavam uma renúncia aos direitos trabalhistas e a precarização das relaçôes de trabalho. O PL 939/2011, por sua vez, de autoria da deputada federal Luci Choinacki (PT-SC), dispunha sobre a escolha da presidência do órgão colegiado do Serviço Nacional de Aprendizagem Rural (Senar) e sobre recursos, tendo recebido apoio da Contag. Frente ao PL 1.463/2011, proposto pelo deputado federal Sílvio Costa (PTB-PE), contudo, os trabalhadores rurais se posicionaram pela rejeiçâo. O PLP 591/2010 e o PL 939/2011 foram arquivados, ao passo que o PL 1.463/2011, que instituía o Código do Trabalho, foi retirado de tramitaçáo por seu autor.

O PDC 2.841/2010, apresentado pela Representaçáo Brasileira no Parlamento do Mercosul, aprovava o Regulamento do Fundo de Agricultura Familiar do Mercosul (FAF Mercosul), adotado pela Decisão CMC 06/09 da XXXVII Reunião Ordinária do
Conselho do Mercado Comum (CMC), realizada em Assunção no dia 23 de julho de 2009; recebeu apoio da entidade, assim como o PL 3.979/2008. De autoria do deputado federal Adáo Pretto (PT-RS), esse projeto estabelecia normas para as relaçóes jurídicas entre a agroindústria e o produtor rural integrado. Por outro lado, a Contag foi contrária ao PL 4.302/1998, de autoria do Poder Executivo, que dispunha sobre relaçōes de trabalho. Notadamente, a rejeição se devia à aplicaçáo da medida ao campo, dados os altos índices de informalidade dessas relações no meio rural. O PL 4.529/2004, por sua vez, foi apresentado por comissão especial voltada para políticas públicas para a juventude, e dispunha sobre o Sistema Nacional de Juventude (Sinajuve), tendo recebido apoio da Confederação.

Para mensurar a taxa de sucesso legislativo, seguiu-se metodologia desenvolvida por Mancuso (2007), que a aplicou à análise da Agenda Legislativa da Indústria (CNI). Sucesso e insucesso são de diferentes tipos: considera-se um resultado como sucesso quando a Contag foi favorável a uma proposiçáo aprovada (ganho) ou contrária a uma proposiçáo rejeitada ou arquivada (alivio); o insucesso ocorre quando a entidade apoiou uma proposição rejeitada (frustração) ou foi contrária a uma proposição aprovada (perda).

A análise dessas proposiçóes revela que a Contag teve uma taxa de sucesso de $51,85 \%$. Considerando a tipologia aplicada, a Tabela 2 apresenta os resultados das 27 proposiçôes, destacando o sucesso legislativo do tipo ganho, que correspondeu a $40,74 \%$. Entre os casos de insucesso, a maior parte $(40,74 \%)$ foi do tipo frustração.

Embora os estudos de Mancuso (2007) e Santos (2011) apontem para uma taxa de sucesso significativamente superior para a $\mathrm{CNI}$ em sua Agenda Legislativa (entre 63\% e 66\%), esses resultados não são diretamente comparáveis àqueles encontrados

Tabela 2 - Sucesso e insucesso por tipo de resultado

\begin{tabular}{cccc}
\hline \multirow{2}{*}{ Sucesso } & Ganho & $\mathbf{1 1 ( 4 0 , 7 4 \% )}$ & \multirow{2}{*}{$\mathbf{1 4}(\mathbf{5 1 , 8 5 \% )}$} \\
\cline { 2 - 3 } & Alívio & $\mathbf{3 ( 1 1 , 1 1 \% )}$ & \multirow{2}{*}{$13(48,15 \%)$} \\
\cline { 2 - 3 } Insucesso & Frustraçáo & $11(40,74 \%)$ & \\
\hline Total & Perda & $2(7,40 \%)$ & \\
\hline
\end{tabular}

Fonte: Elaborado pelos autores a partir de dados da Contag (2018). 
neste artigo. Verifica-se como positiva a obtenção de sucesso legislativo em aproximadamente metade da agenda legislativa da Contag, especialmente pelo sucesso do tipo ganho (40,74\%) ser mais significativo que o do tipo alivio (11,11\%). Enquanto no primeiro caso confirma-se um resultado concreto, o segundo equivale a evitar uma possível perda, que pode ser de caráter momentâneo. Isso não significa, contudo, menosprezar o fato de que, em alguns casos, barrar uma iniciativa de lei pode ser mais relevante, em termos comparativos, do que aprovar uma proposição. De qualquer forma, assume-se que a mudança do status quo tem um peso maior do que sua manutenção. Tendo isso em vista, pretende-se compreender quais fatores incidem sobre o sucesso legislativo desse grupo de interesse.

\section{Configuraçóes causais e hipóteses}

A estratégia empírica, aqui, foi usar a Qualitative Comparative Analysis (QCA), método que permite a análise sistemática de combinaçóes de condiçōes causais para identificar configuraçôes que produzem determinado resultado de interesse. Cabe ressaltar que a opção pelo QCA se deve, por um lado, ao número limitado de casos e, por outro, à complexidade da influência dos grupos de interesse, fenômeno que demanda um olhar qualitativo e, portanto, capaz de captar aspectos contextuais. Desse modo, como afirmam Ragin e Strand (2008, p. 431-432):

O objetivo da análise comparativa qualitativa (QCA) é identificar as diferentes combinaçóes de condiçóes causais relacionadas a um resultado. $\mathrm{O}$ pesquisador normalmente se concentra em um resultado qualitativo e procura identificar as diferentes condições conjunturais que produzem esse resultado. Desta forma, o QCA permite a complexidade causal - pela possibilidade de que nenhuma causa sozinha possa ser necessária ou suficiente. Ao contrário, as causas são vistas como condições INUS: partes insuficientes mas necessárias de condiçôes combinadas não necessárias mas suficientes. ${ }^{4}$ (Mackie, 1965)
O sucesso legislativo da Contag, variável dependente, comporta-se de forma dicotômica (sucesso e insucesso) e é definido sob certas condiçôes. Schlozman e Tierney (1986), por exemplo, afirmam que a influência do lobby sobre um tema está condicionada à ausência de uma oposição do público e de outros interesses organizados. Em sua análise sobre a influência do lobby do setor industrial no comportamento dos deputados brasileiros, Santos (2011) verificou, por sua vez, que seu efeito foi maior nas proposiçōes nas quais os interesses da CNI e do Poder Executivo estavam alinhados. Tendo isso em vista, as condições causais estabelecidas a partir dos estudos sobre grupos de interesse são: 1. alinhamento com o Poder Executivo; 2. mobilizaçâo de massa; 3. presença de grupos opositores; e 4. opinião pública. Sobre a estratégia de coleta de dados, deve-se destacar que, para contextualizar as proposiçôes legislativas e as condições causais identificadas, foram utilizados sobretudo os portais da Câmara dos Deputados e da Contag, além de notícias que revelavam a manifestação de outros atores sobre a proposta ou a ocorrência de alguma mobilização. Na sequência, serão discutidas as condiçōes causais incluídas no modelo e os resultados.

\section{Alinhamento com o Poder Executivo}

A exemplo dos estudos sobre o presidencialismo de coalizão no Brasil, a literatura especializada aponta o Poder Executivo como o principal legislador. Nessa direção, Figueiredo e Limongi $(2001 ; 2002)$ assinalam que, para legisladores influenciarem individualmente a alocação de recursos, questóes de matéria orçamentária são reduzidas às possibilidades derivadas do arcabouço institucional. Para os autores, os parlamentares, individualmente, não têm como colocar em xeque o Executivo, e, por conseguinte, delegam poder aos líderes partidários. Desse modo, "sob a Constituição de 1988, o Executivo se constituiu no principal legislador de jure e de fato" (Figueiredo \& Limongi, 2001, p. 11).

Já Santos (2011, p. 154), ao analisar o sucesso legislativo da indústria, encontra resultados que revelam o papel do alinhamento entre o setor e o Executivo: 
Parte-se do pressuposto que a disciplina partidária no Brasil é alta, e representa o resultado (ou o produto) das prerrogativas constitucionais do Executivo juntamente com a característica de centralizaçáo decisória no interior do Congresso Nacional. Essa centralização se caracteriza pela concentração de poderes nas mãos dos líderes partidários. Assim, agindo de maneira articulada, o governo controla as votações nominais e determina fortemente os resultados políticos na Câmara dos Deputados. (Santos 2011, p. 109-110)

A hipótese é, portanto, que o alinhamento da Contag com o Poder Executivo deve ser uma condiçâo suficiente, ou fazer parte de uma ou mais configuraçôes causais suficientes, para o resultado de interesse.

A variável alinhamento com o Poder Executivo foi construída a partir de dois indicadores: 1 . origem da proposição; e 2. convergência de interesses entre a Contag e o Poder Executivo. Operacionalizada de forma dicotômica, essa variável assume valor 1 quando a proposiçáo tem origem no Executivo e as preferências estão alinhadas - ou seja, quando a Contag se manifesta pela aprovação de uma matéria proposta pelo governo. Em contrapartida, a variável assumiu valor $0 \mathrm{em}$ duas situaçóes: 1 . a proposiçấo teve origem no Poder Legislativo; e 2. a proposição teve origem no Executivo, mas havia divergência de interesses entre a Contag e o governo.

Sabe-se que há problemas neste tipo de estratégia, que desconsidera o alinhamento nos projetos legislativos não propostos pelo Executivo. Contudo, não sendo possível conhecer a posição do Executivo para todas as proposiçóes - a maior parte não chegou ao plenário e, nas comissóes temáticas, não há informações suficientes sobre a manifestação do líder do governo -, a construção da variável pela via da iniciativa legislativa da presidência não deixa de ser um instrumento viável. Além disso, essa operacionalizaçáo elimina o estágio anterior à ação do Executivo e o problema da correlação de forças antagônicas em seu interior. No limite, a despeito de um Executivo complexo, que se constitui em uma ampla rede de interesses que, em certos momentos, podem ser manifestados nas posições conflitivas do presidente com ministérios ou entre ministérios, a produção legislativa do governo representa sua agenda.

Ainda sobre essa variável, é importante destacar que os PLVs foram, em alguns casos e com base em uma análise qualitativa, tratados como iniciativas do Executivo. Qualquer alteração no texto da MP a transforma em um PLV; assim, comparando o conteúdo da proposta inicial (MP) com o texto alterado (PLV), foi possível verificar se o teor e a direçáo da matéria legislativa se mantiveram e, portanto, se ela deveria ser analisada como proposta do Executivo.

\section{Mobilização de massa}

Segundo Almond et al. (2008), os grupos de interesse variam em estrutura, organizaçáo, financiamento e base de apoio, observando-se quatro tipos. Os primeiros, os grupos anômicos, surgem e se desfazem rapidamente. Suas táticas de atuação são sobretudo as manifestaçóes de massa. Os grupos não associativos, assim como os anômicos, raramente são bem organizados e atuam de forma episódica, ainda que baseados em interesses comuns e identidades de etnia, região, religião ou ocupação. Os grupos institucionais, por sua vez, são constituídos por organizaçóes formais, que possuem outras funçôes políticas e sociais além da articulação de interesses; partidos políticos, burocracia, empresas e igrejas são exemplos. Por último, há os grupos associativos, formados para representar os interesses de um determinado segmento. Seus processos decisórios internos são estruturados e seus funcionários, contratados em regime de dedicação exclusiva; o repertório de táticas que empregam é amplo, embora concentrem esforços no lobby. A Contag se enquadra nesta última categoria. Essas diferenças sáo importantes porque a natureza do grupo indica os recursos disponíveis, as táticas para ganhar acesso político e, em consequência, a capacidade de influência.

Isso vai ao encontro do que Binderkrantz (2008) chama "grupos diferentes, estratégias, diferentes". A partir de dados de um survey com grupos de interesse na Dinamarca, a autora verifica que os menos privilegiados recorrem a estratégias indiretas e publicamente visíveis, diferentemente dos grupos mais poderosos, com maior acesso ao Estado. Assim, 
quando os grupos têm dificuldade de contatar diretamente os decison makers, as táticas de lobby indireto ganham importância, particularmente as de baixo custo, como protestos e manifestaçôes. Os objetivos podem ser influenciar a opiniáo pública e atrair a atenção dos atores políticos - para, em última instância, desenvolver canais de acesso direto a eles (Thomas \& Klimovich, 2014).

Assim, como os grupos de interesse de trabalhadores, diferentemente dos empresariais, têm acesso político menor, a mobilização social é uma estratégia amplamente utilizada por eles. A hipótese, portanto, é que a presença dessa condiçáo causal deve ser suficiente, ou fazer parte de uma ou mais configuraçóes causais suficientes, para o resultado de interesse.

A variável mobilização social também é dicotômica, assumindo valor 1 na presença de qualquer manifestaçáo ou protesto para a discussão da matéria legislativa, e valor 0 na ausência dessa condição. Considerou-se "mobilização social" eventos públicos organizados não só pela Contag, mas por quaisquer outros atores afins, como a Marcha das Margaridas, a Comissão Pastoral da Terra, CUT, MSTTR e ONGs ambientais. Para identificar esse tipo de manifestaçáo, recorreu-se à análise qualitativa de notícias publicadas sobre cada proposiçẫo da base de dados. Além dos sites da Câmara dos Deputados e da Contag, foram consultados os portais da grande mídia: O Estado de S. Paulo, BBC News, Folha de S. Paulo e O Globo.

\section{Presença de grupos opositores}

Santos (2011) inclui, no modelo que cria para verificar os determinantes do sucesso legislativo da indústria, a variável "outros grupos", destinada a "medir a quantidade de possíveis opositores que podem estar medindo forças com o lobby da indústria numa determinada votação. Em suma, o grau de oposiçāo que o lobby da indústria enfrenta de outros grupos de pressão" (Santos, 2011, p. 118). O autor chega a um resultado que, embora pouco significativo, mostra "uma diminuiçáo da probabilidade de sucesso da indústria nos casos onde grupos opositores são mais presentes" (Santos, 2011, p. 154).

Diante disso, inclui-se a presença de grupos opositores como condiçâa causal, na hipótese de que sua ausência deve ser suficiente, ou fazer parte de uma ou mais configuraçôes causais suficientes, para o resultado de interesse. Para captar esse contexto, empregou-se um indicador de mobilizaçăo de outros interesses organizados, com preferências divergentes ou concorrentes com as da Contag. Essa mobilizaçáo foi verificada em 1 . propostas de emendas apresentadas por outros grupos para cada uma das 27 proposições; e 2. presença desses grupos com interesses antagônicos nas mídias e sites mencionados. A variável presença de grupos opositores assumiu valor 1 quando se constatou a presença de interesses conflitivos por meio de emendas apresentadas por atores externos ao processo legislativo, e/ou através das notícias publicadas. $\mathrm{Na}$ ausência desse indicador, a variável assumiu valor 0 .

\section{Opiniāo pública}

Schlozman e Tierney (1986) argumentam que uma das condições para o sucesso do lobby dos grupos de interesse é a issue blindada (protegida) da opiniáo pública ou do escrutínio da mídia. Decisóes polêmicas são aquelas que chamam a atenção da opinião pública, seja por sua natureza conflituosa, seja pela publicidade gerada pela oposiçāoo (Santos, 2011, p. 137). Dessa maneira, a influência se dá quando o público está dividido, indiferente ou ignora o assunto (Welch, 1982; Malbin, 1984; Schlozman \& Tierney, 1986); quando a opinião pública é indiferente ao tema ou quando se alinha ao grupo de interesse (Welch, 1982; Malbin, 1984).

Destarte, a hipótese é que a ausência dessa condição faz parte de uma configuraçáo causal suficiente para o resultado de interesse. Para identificar sua presença, adotou-se um indicador de agenda da mídia: se a matéria legislativa foi objeto de discussáo pelos veículos midiáticos, a variável assumiu valor 1 . Se em nenhum momento do processo legislativo ela pautou os jornais, então essa condição estava ausente.

\section{Análise qualitativa comparada: resultados}

Existe alguma combinação causal que assegure sucesso à agenda legislativa da Contag? A Figura 1 identifica todas as combinaçôes possíveis de condiçôes 
Figura 1

Necessidade e suficiência frente ao resultado de interesse

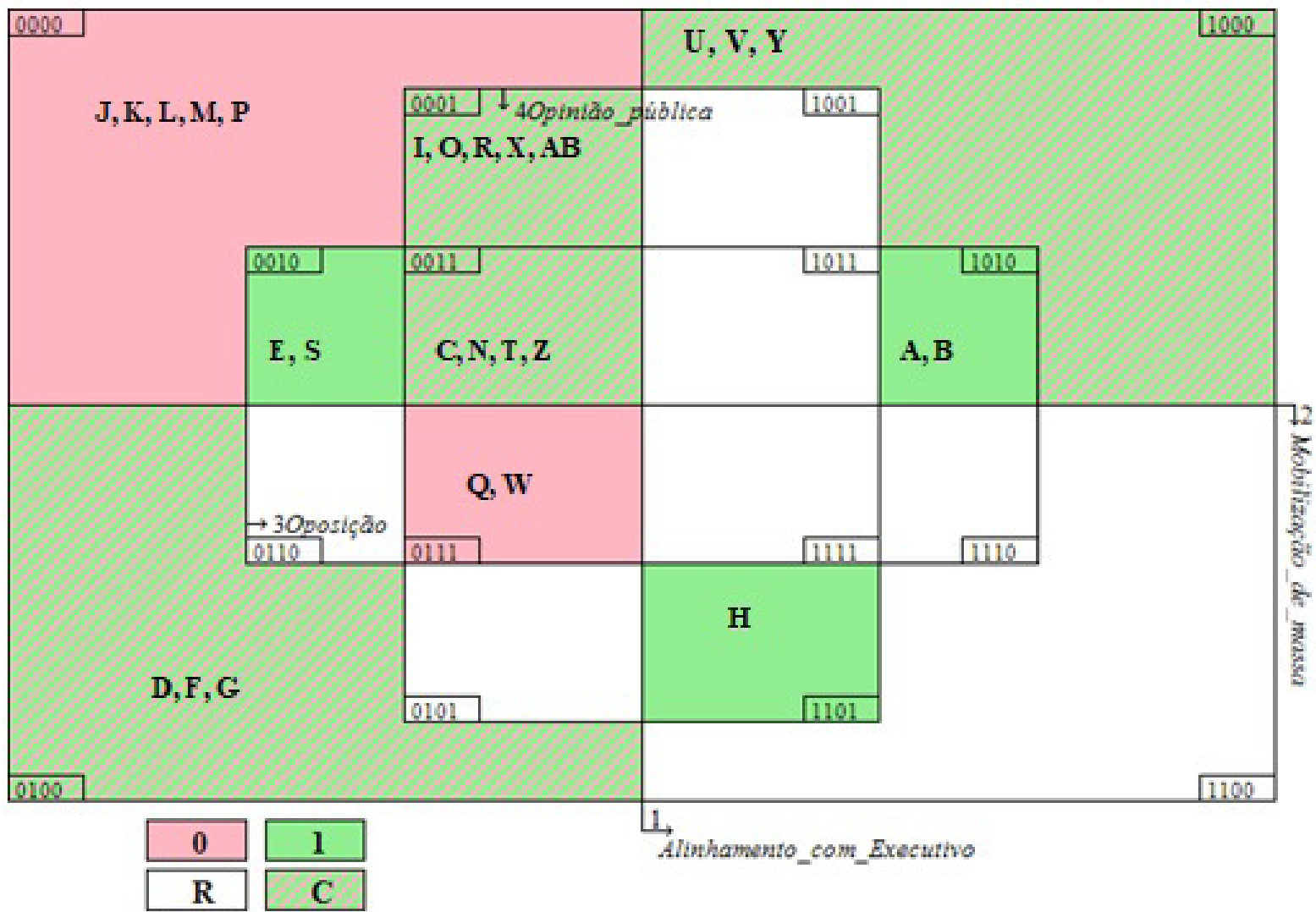

Fonte: elaborado pelos autores a partir de dados da Contag (2018). Legenda: A cor rosa (0) indica os casos de insucesso da Contag; a cor verde (1) se refere aos casos de sucesso da entidade; as áreas rajadas das cores rosa e verde (C) correspondem às configurações com resultados mistos; os campos em branco $(\mathrm{R})$ correspondem às configuraçóes residuais. Notas: $\mathrm{A}-\mathrm{PLV}$ 08/2008; B - PLV 08/2009; C - PLV 09/2009; D - PEC 138/2003; E - PL 203/1991; F - PL 231/2007; G - PLP 306/2008; H - PLP 362/2006; I - PLP 363/2006; J - PEC 394/2005; K - PL 490/1995; L - PLP 591/2010; M - PL 939/2011; N - PL 1463/2011; O - PDC 2841/2010; P - PL 3979/2008; Q - PL 4302/1998; R - PL 4529/2004; S - PL 5887/2009; T - PL 5898/2009; U - PL 5914/2009; V - PL 6852/2006; W - PL 7113/2006; X - PL 7332/2010; Y - PL 8035/2010; $\mathrm{Z}$ - PEC 438-A/2001; AB - PL 8023-A/2010. As proposiçóes foram ordenadas com as letras do alfabeto, conforme sua posição na Tabela 1.

causais e compara as proposiçóes legislativas. As variáveis dicotômicas geraram dezesseis configuraçôes causais.

O retângulo maior da Figura 1 compreende o conjunto das 27 proposiçóes legislativas estudadas. $\mathrm{Na}$ metade direita, encontram-se todas as proposiçôes em que a Contag e o Poder Executivo estiveram alinhados. $\mathrm{Na}$ metade esquerda, as proposiçóes para as quais não houve alinhamento de preferências. Na metade inferior estão as proposiçóes que ensejaram mobilização de massa; na metade superior, as que tramitaram sem que houvesse qualquer manifestação para discuti-las. As condições grupos opositores e opiniāo pública estão representadas nos retângulos internos do diagrama. Todos os casos em que se constatou a presença de grupos opositores estão inseridos no retângulo interno horizontal. As proposiçóes sobre as quais a opinião pública se manifestou estão no retângulo interno vertical. A sobreposição dos quadros divide o plano no maior número de polígonos possíveis.

Como exemplo, considera-se o polígono superior esquerdo, indicado pelo código 0000: aqui estão todas as proposiçóes caracterizadas pela ausência das quatro condiçóes causais. Isto é, para as proposiçóes J, K, L, M e P (PEC 394/2005, PL 490/1995, PLP 591/2010, 
PL 939/2011 e PL 3979/2008, respectivamente) não houve alinhamento entre Contag e Executivo, mobilização de massa, grupos opositores e opinião pública. Por sua vez, o polígono superior direito, com as proposiçóes A e B (PLV 08/2008 e PLV 08/2009, respectivamente), indica alinhamento de preferências entre a Contag e governo, bem como a presença de grupos opositores. No entanto, não se observaram, nesses casos, as condições mobilização de massa e opinião pública.

A variável dependente está representada na Figura 1 pelas cores rosa e verde. A cor rosa (0) indica os casos de insucesso da Contag, ou seja, as proposiçóes correspondentes às letras J, K, L, M, P, Q e W. Por outro lado, a cor verde (1) se refere aos casos de sucesso da entidade, representados pelas letras A, B, E, S e H. Já as áreas rajadas das cores rosa e verde $(\mathrm{C})$ correspondem às configuraçóes com resultados mistos, quando há tanto sucesso quanto insucesso para a entidade (proposiçóes U, V, Y, I, O, R, X, AB, C, N, T, Z, D, F e G). Por último, os campos em branco $(\mathrm{R})$ correspondem às configuraçóes residuais, isto é, aquelas logicamente possíveis, mas sem exemplos entre os casos analisados.

Três situaçóes identificadas na Figura 1 parecem assegurar o sucesso legislativo da Contag: 0010 (PL 203/1991 e PL 5887/2009), 1010 (PLV 08/2008 e PLV 08/2009) e 1101 (PLP 362/2006). Para simplificar esta relação de configuraçóes, considera-se, por exemplo, as duas primeiras (0010 e 1010): sem mobilização e nem tampouco opinião pública, mas havendo grupos opositores, independentemente do alinhamento com o Executivo a Contag alcança sucesso.

A partir deste princípio, a solução parcimoniosa e o processo de minimização lógica ${ }^{5}$ permitem reduzir essas configuraçóes a três situações que parecem oferecer resposta positiva à indagação inicial. Elas são formalmente representadas como:

[1] oposição* opinião pública + (alinhamento* mobilização)

[2] oposição* opinião pública + (alinhamento*opinião pública)

[3] oposição* opinião pública + (mobilização* oposição*opinião pública)
Essas três combinaçóes causais indicam que todos os casos com essas configuraçôes resultaram em sucesso para a Contag. Para dar sentido ao achado, algumas notaçóes devem ser feitas. O QCA se baseia na álgebra booleana, podendo ser aplicadas as seguintes operaçóes básicas: intersecção [E $\left.\left(^{*}\right)\right]$, união [Ou $\left.(+)\right]$ e negação [ausência de $(\sim)$ ]. Assim, a compreensão de cada um dos três modelos se dá a partir dos elementos de conjunção $\left({ }^{*}\right)$, disjunção $(+)$ e negação $(\sim)$. Não se pode, portanto, interpretar as variáveis em separado, e nem as conjunçóes, devendo-se, antes, considerar a disjunção. Na segunda configuração, por exemplo, temos a presença de oposição, em conjunção com a ausência de opinião pública, ou o alinhamento com o governo em conjunção com a opinião pública. Há, aqui, duas conjunçôes: uma que está fora dos parênteses, e outra que está dentro. A conjunção da ausência de opinião pública com a oposição a torna qualitativamente diferente da conjunção da opinião pública com o alinhamento.

Tendo isso em vista, a análise das configurações indica que o sucesso legislativo da Contag é assegurado: (1) na presença de grupos opositores interessados na proposição, não havendo manifestação da opinião pública (PL 203/1991, PL 5887/2009, PLV 08/2008, PLV 08/2009) ou havendo alinhamento entre a entidade e o Poder Executivo, e não havendo mobilização de massa (PLP 362/2006); (2) na presença de grupos opositores, não havendo manifestação da opinião pública ou verificando-se alinhamento e a presença da opinião pública (PLP 362/2006); e (3) na presença de grupos opositores interessados na proposição, sem que haja manifestação da opinião pública, ou na presença de mobilização de massa e da opinião pública, estando ausentes grupos opositores (PLP 362/2006). ${ }^{6}$

O implicante primário presença de oposição e ausência de opiniáo pública aparece como elemento comum a todas as situaçóes que levam ao resultado de interesse. Assim, em contextos nos quais grupos opositores estáo presentes e a opinião pública, ausente, a Contag é bem sucedida, a despeito de haver ou não alinhamento com o Executivo ou mobilização de massa. Isso significa que, diante dessa combinação causal, o êxito da Contag não é prejudicado quando há outros atores com interesses antagônicos. Outrossim, como observado pela literatura especializada, a ausência de 
opiniāo pública pode, nesse cenário, contribuir para o enfraquecimento da oposição, à medida em que ela não ganha publicidade.

O alinhamento entre Contag e Poder Executivo é elemento comum nas configuraçóes 1 e 2 . Todavia, essa condição năo é suficiente para o sucesso. A entidade precisa contar, também, com a mobilizaçáo de massa ou com a presença da opinião pública. Os dois casos indicam que atrair a atenção do público e dos políticos, seja via mobilizaçáo, seja via veículos midiáticos, leva a entidade ao sucesso, quando ela está alinhada ao governo.

Por fim, a análise das configuraçóes revela que a presença de mobilização de massa e da opinião pública, por um lado, e a ausência de grupos opositores, por outro, levam a Contag ao sucesso. Esse resultado indica que, constatando-se as demais condiçōes, o alinhamento com o Poder Executivo é desnecessário, ou seja, ter um importante veto player como parceiro náo é relevante quando não há outros grupos disputando influência, e a proposição recebe atenção via mobilização e opinião pública. Assim, pode-se inferir que nenhuma das condiçóes causais é, sozinha, suficiente e/ou necessária para o sucesso da Contag. Por outro lado, todas fazem parte de pelo menos uma configuração causal suficiente para o resultado de interesse.

\section{Consideraçóes finais}

Este artigo se insere em um esforço mais amplo de pesquisa sobre a atuação política dos trabalhadores rurais representados pela Contag na arena legislativa brasileira. Mais especificamente, busca-se compreender sob quais condições causais se dá o sucesso legislativo da entidade na Câmara dos Deputados. Para tanto, lança-se mão da análise comparada de um número intermediário de casos, a partir da aplicação de QCA. Foram analisadas 27 proposições legislativas referentes à agenda legislativa da Contag entre 2007 e 2015, e que já tiveram sua tramitação encerrada. Essas proposiçóes estão presentes em documentos de reivindicaçáo como o Grito da Terra Brasil. A variável dependente se comporta de forma dicotômica (sucesso e insucesso). Já as condiçôes causais são: 1. alinhamento com o Poder Executivo; 2. mobilização de massa; 3. presença de grupos opositores; $\mathrm{e} 4$. opiniáo pública.

Criada em 1963, a Contag obteve importantes conquistas, a exemplo do Pronaf e do Pnae. Por outro lado, pautas centrais, como o avanço das relaçóes de trabalho no campo e a reforma agrária, mantêm-se ofuscadas. Ainda assim, o artigo demonstra que a entidade se coaduna com o alargamento da atuaçáo legislativa dos grupos de interesse no período pós-redemocratização, como demonstrado pela literatura especializada. No sítio eletrônico da Contag, é possível encontrar as proposiçóes legislativas de interesse da entidade no Congresso Nacional. $\mathrm{Na}$ Câmara dos Deputados, constam 52 proposiçóes com posicionamento definido, de um total de 820 proposiçōes elencadas. Dessas 52, a Contag é favorável a 22, contrária a 24 e indiferente a seis.

Parte significativa das proposiçôes de interesse da Contag no período em estudo constitui-se em projetos de lei: quinze, ou $60 \%$ do total. Das 27 , somente cinco são de autoria do Poder Executivo; quatro delas foram apresentadas durante os governos do PT e uma, no governo do PSDB. A análise dessas proposiçóes revela uma taxa de sucesso de $51,85 \%$.

Para cada condiçáo causal elencada, há uma hipótese correspondente: 1 o alinhamento com o Poder Executivo é condição suficiente ou faz parte de uma ou mais configuraçóes causais suficientes para o resultado de interesse; 2 . acredita-se que a presença de mobilizaçáo de massa deve ser suficiente, ou fazer parte de uma ou mais configuraçóes causais suficientes; 3 . ausência de grupos opositores configura condição causal suficiente, ou parte de uma ou mais configuraçóes causais suficientes para o resultado de interesse; e 4. a ausência da opiniáo pública como condição causal, ao lado da ausência de grupos opositores, cria uma configuraçáo causal suficiente para o resultado de interesse.

Os resultados revelam que três configuraçōes parecem assegurar o sucesso legislativo da Contag: 1. presença de grupos opositores interessados na proposição e ausência de manifestação da opiniáo pública (PL 203/1991, PL 5887/2009, PLV 08/2008, PLV 08/2009) ou alinhamento da Contag com o Poder Executivo e presença de mobilizaçáo de massa (PLP 362/2006); 2. presença de grupos opositores e ausência de manifestação da opinião pública ou alinhamento 
e presença da opinião pública (PLP 362/2006); e 3. presença de grupos opositores interessados na proposição e ausência de manifestação da opiniấo pública ou presença de mobilização de massa e da opiniāo pública, com ausência de grupos opositores (PLP 362/2006). Além disso, os resultados indicam que nenhuma condição causal é, sozinha, condição suficiente e/ou necessária para o resultado de interesse.

Cabe ressaltar que esses resultados devem ser lidos a partir de duas consideraçóes acerca das limitaçóes deste artigo, contudo. A primeira se deve ao seu caráter parcial: trata-se de uma primeira reflexão, integrada a um esforço de pesquisa mais amplo sobre a representação de interesses da Contag e de seu sucesso legislativo. Nesse sentido, é necessário incluir como condição causal a intensidade do lobby da entidade, de modo a averiguar seu papel explicativo para o resultado de interesse. A coleta de dados para a composição dessa condição causal, entretanto, demanda a aplicação de outros instrumentos de pesquisa, tais como entrevistas semiestruturadas de representantes da Confederação.

Outra limitação se encontra no potencial explicativo das condiçôes causais aqui mobilizadas, que parecem insuficientes frente àquelas presentes na literatura especializada. Além disso, deve-se considerar, por exemplo, que é problemático dicotomizar a condição causal grupos opositores, já que o conflito é intrínseco ao processo decisório de qualquer política pública. Ainda nesse sentido, a intensa atuação do PT na proposição de legislaçóes de interesse da Contag demonstra a necessidade de recompor a condiçáo causal alinhamento com o Poder Executivo.

Note-se, ainda, que, para o QCA, a operacionalização de um número grande de variáveis independentes é inadequada, uma vez que um número intermediário de casos pode gerar um desenho de pesquisa indeterminado. Por outro lado, é interessante compor macro variáveis que permitam uma apreensão mais robusta das condições causais. Por fim, como a Contag integra uma rede da qual fazem parte também MSTTR, MST e outros atores, seu sucesso legislativo não deve ser considerado descolado dessa estratégia de atuação política.

O presente artigo propóe, em suma, um primeiro passo para a compreensão do sucesso legislativo dos trabalhadores e trabalhadoras rurais organizados, sob a perspectiva da influência, com o objetivo de ensejar novas possibilidades de pesquisa no campo de estudo dos grupos de interesse.

\section{Agradecimentos}

A primeira versão deste artigo foi apresentada no 42 Encontro Anual da Associação Nacional de PósGraduação e Pesquisa em Ciências Sociais (Anpocs), no grupo de trabalho (GT) "Dinheiro, interesses e democracia: a influência dos recursos financeiros no sistema político". Na oportunidade, recebemos comentários importantes para o aperfeiçoamento do trabalho; registramos nosso agradecimento, por eles, aos professores Wagner Mancuso e Rodrigo Horochovski, coordenadores do GT. Agradecemos, ainda, à Coordenaçáo de Aperfeiçoamento de Pessoal de Nível Superior (Capes) e à Fundação de Amparo a Pesquisa do Estado de Minas Gerais (Fapemig) pelo financiamento de nossas bolsas de pós-graduação; à Contag, na pessoa de Adriana Fetzner, pelo apoio no processo de coleta de dados; ao professor Manoel Santos, pelos comentários sobre este artigo; a Breno Marisguia, pelo apoio na aplicação do QCA; a Laetitia Jourdan, pela revisão de trechos traduzidos; e aos pareceristas anônimos da RBCS, por seus comentários e sugestóes.

\section{Notas}

1 Estudos mais recentes se voltam para a influência exercida nas agências reguladoras (Baird, 2017), no Supremo Tribunal Federal (Carvalho et al., 2016) e nas comissóes parlamentares (Cesário, 2016).

2 Optou-se por considerar os projetos de lei de conversão - proposiçáo apresentada a uma medida provisória (MP) quando o relator da matéria conclui, no parecer, por alguma alteraçáo no texto - como sendo de autoria de seus respectivos relatores.

3 Outra modificação impactava a venda das terras: pelo texto original, os novos donos poderiam fazê-lo após dez anos da regulamentação; o PLV permite vender propriedades de mais de 400 hectares três anos após a titulação.

4 Tradução dos autores.

5 A solução parcimoniosa inclui os resíduos, isto é, os casos para os quais não há exemplos históricos. Assim, essa solução considera as configuraçóes logicamente possíveis, não havendo, contudo, exemplos delas entre os casos estudados. Por sua vez, o processo de minimização identifica as configuraçôes causais verdadeiras que são exatamente iguais, à exceção de uma condição, isto é, uma 
condição que está presente na primeira configuração, mas ausente na segunda. A minimização lógica simplifica as configuraçóes suficientes identificadas. As configuraçóes que não podem ser simplificadas são chamadas de implicantes primários (Pérez-Liñán, 2010).

6 Como se pode perceber, o PLP 362/2006 amolda-se em três implicantes primários: 1. alinhamento e mobilizaçáo; 2. alinhamento e opinião pública; e 3. mobilização e opinião pública, com ausência de oposição. Isso é possível porque, em relação a esta proposição, a Contag estava alinhada com o governo, houve mobilização para sua aprovação, a opinião pública se manifestou e não havia grupos opositores presentes. Além disso, o implicante primário é o resultado de um processo de minimizaçáo lógica, como explicado. Deve-se ressaltar, ainda, que os exemplos constantes nessa análise são únicos, entre as proposiçôes incluídas neste estudo.

\section{BIBLIOGRAFIA}

ABLER, David G. (1991), "Campaign contributions and house voting on sugar and dairy legislation". American Journal of Agricultural Economics, v. 73, n. 1, pp.11-17.

ALMOND, Gabriel; POWELL, G. Bingham; DALTON, Russell J. \& STROM, Kaare. (2008), Comparative Politics Today: A Theoretical Framework, Pearson, Longman.

BAIRD, Marcello Fragano. (2017), Redes de influência, burocracia, política e negócios na Agência Nacional de Saúde Suplementar (ANS). Tese de Doutorado. Programa de Pós-graduação em Ciência Política da Universidade de São Paulo, São Paulo.

BAUMGARTNER, Frank \& LEECH, Beth. (1998), Basic Interest: The Importance of Groups in Politics and in Political Science. Princeton University Press.

BINDERKRANTZ, Anne Skorkjaer. (2008), "Different Groups, Different Strategies: How Interest Groups Pursue Their Political Ambitions". Scandinavian Political Studies, v. 31, n. 2, pp.173-200.

BRASIL, Congresso Nacional. Câmara dos Deputados. (2006), Projeto de Lei Complementar no 362 de 2006. Disponível em: https:// www.camara.leg.br/proposicoes Web/ fichadetramitacao?idProposicao $=325847$, consultado em 26 ago. 2018.
BRASIL, Congresso Nacional. Câmara dos Deputados. (2007), Projeto de Lei no 231 de 2007. Disponível em: https://www.camara.leg.br/proposicoesWeb/ fichadetramitacao?idProposicao $=342456$, consultado em 26 ago. 2018.

BRASIL, Congresso Nacional. Câmara dos Deputados. Departamento de Taquigrafia, Revisão e Redação. (2008a), Discurso do deputado federal Assis do Couto. Disponível em: https://www. camara.leg.br/internet/SitaqWeb/TextoHTML. asp?etapa $=5 \&$ nuSessao $=062 \cdot 2 \cdot 53$. O\&nuQuarto $=65$ $\&$ nuOrador $=1 \&$ nuInsercao $=9 \& \mathrm{dt}$ Horario Quarto $=16: 08 \& s g$ FaseSessao $=O D \& D a t a=$ 09/04/2008, consultado em 26 ago. 2018.

BRASIL, Congresso Nacional. Câmara dos Deputados. (2008b), Projeto de Lei Complementar no 306 de 2008. Disponível em: https:/www.camara.leg.br/proposicoesWeb/ fichadetramitacao?idProposicao $=394079$, consultado em 26 ago. 2018.

BRASIL. Congresso Nacional. Câmara dos Deputados. (2009), Projeto de Lei de Conversão no 8 de 2009. Disponível em: https:// www.camara.leg.br/proposicoesWeb/prop_ mostrarintegra? codteor $=647747$ \& filename= $\mathrm{PLV}+8 / 2009+\% 3 \mathrm{D} \% 3 \mathrm{E}+\mathrm{MPV}+455 / 2009$, consultado em 26 ago. 2018.

BRONARS, Stephen G. \& LOTT JR., John R. (1997), "Do campaign donations alter how a politician votes? Or, do donors support candidates who value the same things that they do?". Journal of Law and Economics, v. 40, n. 2, pp.317-350.

CARVALHO, Maria Izabel Valladão de. (2010), "Condicionantes Internacionais e Domésticos: Brasil e o G-20 nas Negociaçôes Agrícolas da Rodada Doha". Dados, v. 53, n. 2, pp.405-445.

CARVALHO, Priscila Delgado de. (2011), Ação coletiva transnacional e Mercosul: organizaçôes da sociedade civil do Brasile do Paraguai na construção da Reunião Especializada sobre Agricultura Familiar (Reaf). Dissertação de Mestrado. Programa de Pós-graduação em Ciência Política da Universidade de Brasília, Brasília.

CARVALHO, Ernani Rodrigues de; SANTOS, Manoel Leonardo; GOMES NETO, José Mário Wanderley $\&$ BARBOSA, Leon Victor de Queiroz. (2016), 
"Judicialización de la política y grupos de interés em Brasil: Intereses, estratégias y resultados". America Latina Hoy, v. 72, pp.59-88.

CESÁRIO, Pablo Silva. (2016), "Redes de influência no Congresso Nacional: como se articulam os principais grupos de interesse". Revista de Sociologia e Politica, v. 24, n. 59, pp.109-127.

CONTAG, Confederação Nacional dos Trabalhadores na Agricultura. (2003a), "Revista 40 anos". Disponível em: http://www.contag.org.br/imagens/ CONTAG-Revista40anos.pdf, consultado em: 8 abr. 2018.

CONTAG, Confederação Nacional dos Trabalhadores na Agricultura. (2003b), "Grito da Terra 2003". Disponível em: http://www.contag.org.br/imagens/ f2003-pauta-do-gtb-unificada.doc, consultado em: 8 abr. 2018.

CONTAG, Confederação Nacional dos Trabalhadores na Agricultura. (2009), "Grito da Terra 2009". Disponível em: http://www.contag.org.br/ imagens/f1620contagmaiojunho.pdf, consultado em: 8 abr. 2018.

CONTAG, Confederação Nacional dos Trabalhadores na Agricultura. (2013a), “CONTAG 50 anos: apresentação”. Disponível em: http://www.contag.org.br/index. php? modulo=portal\&acao $=$ interna\&codpag= 432\&ap=1\&nw=1, consultado em: 8 abr. 2018.

CONTAG, Confederação Nacional dos Trabalhadores na Agricultura. (2013b), "Grito da Terra 2013". Disponível em: http://www.contag.org.br/ arquivos/portal/GTB\%202013_PAUTA\%20 CONGRESSO.pdf, consultado em: 08 abr. 2018.

CONTAG, Confederação Nacional dos Trabalhadores na Agricultura. (2018), Portal da Contag. Disponível em: http://www.contag.org.br/index. php, consultado em: 8 abr. 2018.

DAVIS, Frank L. (1993), "Balancing the perspectives on PAC contributions: in search of an impact on roll calls". American Politics Quarterly, v. 21, n. 2, pp.205-222.

DINIZ, Eli \& BOSCHI, Renato. (2004), Empresariado, Interesses e Mercado: Dilemas do desenvolvimento do Brasil. Belo Horizonte/Rio de Janeiro, Editora UFMG/IUPERJ.
DOW, Jay K. \& ENDERSBY, James W. (1994), "Campaign contributions and legislative voting in the California Assembly". American Politics Quarterly, v. 22, n. 3, pp.334-353.

EVANS, Diana M. (1986), "PAC contributions and roll-call voting: conditional power", in A. J. Cigler $\&$ B. A. Loomis (orgs.), Interest Group Politics, Washington DC: Congressional Quarterly Press. FIGUEIREDO, Argelina Cheibub \& LIMONGI, Fernando. (2001), Executivo e Legislativo na nova ordem constitucional. Rio de Janeiro: FGV.

FIGUEIREDO, Argelina Cheibub \& LIMONGI, Fernando. (2002), "Incentivos Eleitorais, Partidos Políticos e Política Orçamentária”. Dados, v. 45, n. 2, pp.303-339.

HALL, Richard L. \& WAYMAN, Frank W. (1990), "Buying Time: moneyed interests and the mobilization of bias in Congressional Committees". American Political Science Review, v. 84, n. 3, pp.797-820.

HOLIAN, David B.; KREBS, Thomas B. \& WALSH, Michael H. (1997), "Constituency opinion, Ross Perot, and Roll-Call Behavior in the U.S. House: The Case of the NAFTA". Legislative Studies Quarterly, v. 22, n. 3, pp.369-392.

LANGB EIN, Laura I. (1993), "PACs, lobbies, and political conflict: the case of gun control". Public Choice, v. 77, n. 3, pp.551-572.

MACKIE, John L. (1965), "Causes and Conditionals". American Philosophical Quarterly, v. 2, n. 4, pp.245-264.

MALBIN, Michael J. (1984), Money and politics in the United States: financing elections in the 1980s. Chatham House Publishers.

MANCUSO, Wagner Pralon. (2007), O lobby da indústria no Congresso Nacional: Empresariado e politica no Brasil contemporâneo. São Paulo: Humanitas.

PÉREZ-LIÑÁN, Aníbal. (2010), “El método comparativo y el análisis de configuraciones causales". Revista Latinoamericana de Política Comparada, v. 3, n. 3, pp.125-148.

RAGIN, Charles C. \& STRAND, Sarah Ilene. (2008), "Using Qualitative Comparative Analysis 
to Study Causal Order". Sociological Methods \& Research, v. 36, n. 4, pp.431-441.

SABATO, Larry J. (1985), PAC power: inside the world of political action committees. Nova York: W.W. Norton.

SANTOS, Manoel Leonardo. (2011), O Parlamento sob influência: o lobby da indústria na Câmara dos Deputados. Tese de Doutorado. Programa de Pósgraduação em Ciência Política da Universidade Federal de Pernambuco, Recife.

SANTOS, Manoel Leonardo. (2014), "Representação de interesses na arena legislativa: os grupos de pressão na Câmara dos Deputados (1983-2012)". Texto para discussão IPEA, n. 1975, pp.5-39.

SANTOS, Manoel Leonardo; SILVA, Mariana Batista da; FILHO, Dalson Britto Figueiredo \& ROCHA, Enivaldo Carvalho. (2015), "Financiamento de campanha e apoio parlamentar à Agenda Legislativa da Indústria na Câmara dos Deputados". Opinião Pública, v. 21, n. 1, pp.33-59.

SCARROW, Susan E. (2007), "Political Finance in Comparative perspective". Annual Review of Political Science, v. 10, pp.193-210.

SCHERER-WARREN, Ilse. (2007), "A política dos movimentos sociais para o mundo rural". Estudos Sociedade e Agricultura, v. 15, n. 1, pp.5-22.
SCHLOZMAN, Kay Lehman \& TIERNEY, John T. (1986), Organized interests in American democracy. Nova York: Harper and Row.

STRATMANN, Thomas. (2002), "Can special interests buy congressional votes? Evidence from financial services legislation". Journal of Law and Economics, v. 45, n. 2, pp.345-373.

STRATMANN, Thomas. (2005), "Some talk: Money in politics. A (partial) review of the literature". Public Choice, v. 124, n. 1, pp.135-156.

THOMAS, Clive S. \& KLIMOVICH, Kristina. (2014), "Interest groups and lobbying in Latin America: theoretical and practical considerations". Journal of Public Affairs, v. 14, n. 3, pp. 165-182.

WAWRO, Gregory. (2001), "A panel probit analysis of campaign contributions and roll-call votes". American Journal of Political Science, v. 45, n. 3, pp.563-579.

WELCH, William P. (1982), "Campaign contributions and legislative voting: milk money and dairy price supports". Western Political Quarterly, v. 35, pp.478-495.

WRIGHT, John R. (1990), "Contributions, lobbying, and committee voting in the U.S. House of Representatives". American Political Science Review, v. 84, n. 2, pp.417-438. 


\section{TRABALHADORES RURAIS NO PARLAMENTO: O LOBBY DA CONTAG NA CÂMARA DOS DEPUTADOS (2007-2015)}

\section{Barbara Salatiel Borges, Paula Vivacqua de Souza Galvão Boarin, Ciro Antônio da Silva Resende e Lucas Henrique Ribeiro da Silva}

Palavras-chave: Contag; Lobby; Poder Legislativo brasileiro; Trabalhadores rurais; Qualitative Comparative Analysis.

$\mathrm{O}$ artigo analisa o lobby da Confederação Nacional dos Trabalhadores e Trabalhadoras Rurais (Contag) na Câmara dos Deputados entre 2007 e 2015. Os dados utilizados referem-se majoritariamente à agenda legislativa da Contag. São analisadas 27 proposiçôes legislativas que já tiveram a tramitaçáo encerrada. Devido ao número limitado de casos, a estratégia empírica consiste no uso de Qualitative Comparative Analysis (QCA), método que permite analisar de forma sistemática combinações de condiçóes causais, com o objetivo de identificar configuraçóes que produzem determinado resultado. Os resultados indicam uma taxa de sucesso legislativo de cerca de 50\%, não se registrando condição causal que seja, sozinha, suficiente e/ou necessária para o resultado de interesse. Ao analisar resultados políticos à luz de condiçôes causais institucionais, o artigo visa contribuir para os estudos sobre influência, a partir da perspectiva de um segmento essencial à compreensão do Brasil moderno.

\section{RURAL WORKERS IN PARLIAMENT: CONTAG'S LOBBY AT THE CHAMBER OF DEPUTIES (2007-2015)}

Barbara Salatiel Borges, Paula Vivacqua de Souza Galvão Boarin, Ciro Antônio da Silva Resende and Lucas Henrique Ribeiro da Silva

Keywords: Contag; Lobby; Brazilian Legislative; Rural workers; Qualitative Comparative Analysis.

The article analyzes the lobby of the National Confederation of Rural Workers (Contag) in the Chamber of Deputies, between 2007 and 2015. The assessed data mostly refer to Contag's legislative agenda. A total of 27 already closed legislative proposals are analyzed. Due to the limited number of cases, the empirical strategy consists of the use of a Qualitative Comparative Analysis (QCA), a method that allows the systematic analysis of combinations of causal conditions, in order to identify configurations that produce a certain result. The results indicate a legislative success rate of about $50 \%$. with no record of a causal condition that is alone, sufficient and/or necessary for the result of interest. By analyzing political results in the light of institutional causal conditions, the article aims to contribute to studies on influence from the perspective of a segment paramount in understanding modern Brazil.

\section{TRAVAILLEURS RURAUX AU PARLEMENT LE $L O B B Y$ DE LA CONTAG A LA CHAMBRE DES DEPUTES (2007-2015)}

\section{Barbara Salatiel Borges, Paula Vivacqua de Souza Galvão Boarin, Ciro Antônio da Silva Resende et Lucas Henrique Ribeiro da Silva}

Mots-clés: Contag; lobby; pouvoir législatif brésilien; travailleurs ruraux; analyse qualitative comparative.

Cet article analyse le lobby de la Confédération nationale des travailleurs de l'agriculture (Contag) au sein de la Chambre des Députés entre 2007 et 2015. Les données utilisées proviennent majoritairement de l'agenda législatif de la Contag, à savoir 27 propositions ayant déjà fait l'objet d'une procédure législative. En raison du nombre limité de cas, la stratégie empirique repose sur l'utilisation de l'analyse qualitative comparative (QCA), une méthode qui étudie de forme systématique les combinaisons de conditions causales pour identifier des configurations qui produisent un résultat déterminé. Les résultats indiquent un taux de réussite législative d'environ $50 \%$, sans condition causale suffisante et/ou nécessaire pour le résultat d'intérêt. Du point de vue de l'analyse des résultats politiques à la lumière des conditions causales institutionnelles, le présent travail se veut une contribution pour les études sur l'influence à partir de la perspective d'un segment essentiel à la compréhension du Brésil moderne. 